\title{
Corrigendum
}

\section{Reproductive state and choline intake influence enrichment of plasma lysophosphatidylcholine-DHA: a post-hoc analysis of a controlled feeding trial - CORRIGENDUM}

Kevin C. Klatt, Melissa Q. McDougall, Olga V. Malysheva, J. Thomas Brenna, Mark S. Robertson and Marie A. Caudill

(First published online $16^{\text {th }}$ August 2019)

doi: https://doi.org/10.1017/S0007114519002009

\section{FINANCIAL SUPPORT}

The original research was supported by the Egg Checkoff, through the Egg Nutrition Center; the Beef Checkoff, through the National Cattlemen's Beef Association and the Nebraska Beef Council; the USDA Cooperative State Research, Education, and Extension Service, special research grant 00444528; and the Affinito-Stewart Grants Program, through the President's Council of Cornell Women. This current material is based upon work that is supported by the National Institute of Food and Agriculture U.S. Department of Agriculture, HATCH under accession number 1013729. Salary for KCK was provided from a National Institute of Health Training Grant (T32HD087137). The funding sources had no role in the study design, interpretation of the data, or publication of results. 